\title{
A comparative study of phosphorus availability in an acidic soil and an alkaline soil amended with organic and inorganic phosphorus sources
}

\author{
Ismat Ara ${ }^{1}, \mathrm{Md}$. Shoffikul Islam ${ }^{1 *}$, Md. Abul Kashem ${ }^{1}$, Khan Towhid Osman $^{1}$ \\ ${ }^{1}$ Department of Soil Science, University of Chittagong, Chittagong-4331, Bangladesh. *Corresponding author: \\ msislam@cu.ac.bd
}

\begin{abstract}
An incubation study was conducted to investigate the effects of adding cow manure (CM), poultry manure (PM), city waste (CW) and triple super phosphate (TSP) on extractable P in a sandy loam acidic soil (Aquepts) and a silt loam alkaline soil (Fluvents). Phosphorus was added at a rate of $200 \mathrm{mg} \mathrm{P} \mathrm{kg}^{-1}$ to the soil in the forms of CM, PM, CW and TSP. The soil was incubated at field capacity for 15, 30 and 60 days after which the P sources were extracted with Olsen, Kelowna, Mehlich-3, and Bray and Kurtz-II extractants. Regardless of the extractants and soils, after 15 days of incubation, the highest extractable P source was the TSP (88-97 $\mathrm{mg} \mathrm{kg}^{-1}$ as Olsen P), and the lowest was the CW (11-15 $\mathrm{mg} \mathrm{kg}^{-1}$ as Olsen P). The extractable P levels with the CM (41-48 $\mathrm{mg} \mathrm{kg}^{-1}$ as Olsen $\mathrm{P}$ ) and PM (71-73 $\mathrm{mg} \mathrm{kg}^{-1}$ as Olsen P) were between the extractable P levels with the TSP and CW. Extractable P in the soils with the organic amendments increased slightly with increasing incubation time from 15 to 60 days. With the TSP, extractable P decreased sharply in the acidic soil, while it decreased gradually in the alkaline soil. In both soils, extraction efficiency was in the order of Bray and Kurtz-II $>$ Mehlich-3> Kelowna $>$ Olsen. The efficiency of the added $\mathrm{P}$ as measured by $\mathrm{NaHCO}_{3}$ increased with the organic amendments, while the efficiency decreased with the TSP with days of incubation. This study indicates that soil samples taken 30 days after the addition of CM and PM in the soil might reflect the most plant-available P.
\end{abstract}

Keywords: Phosphorus, extractants, organic amendments, soils, incubation. 


\section{Introduction}

Soil $\mathrm{P}$ chemistry is different in alkaline and acidic soils. The availability of $\mathrm{P}$ for plant growth is influenced by soil organic matter, $\mathrm{pH}$, and exchangeable and soluble aluminum (Al), iron (Fe), and calcium (Ca) (Ulrich and Schnug, 2013). Phosphorus is generally most available to crops at a soil $\mathrm{pH}$ of 6 and 7. In acidic soils, $\mathrm{P}$ can be dominantly sorbed by Fe/Al oxides and hydroxides (Adnan et al., 2003) as well as by clay minerals and form various complexes (Arai and Sparks, 2007). In alkaline soils, P retention is dominated by precipitation reactions, although $\mathrm{P}$ can also be adsorbed on the surface of Ca carbonate (Naeem et al., 2013) and clay minerals (Devau et al., 2010) and become unavailable to plants (Arai and Sparks, 2007). As $\mathrm{P}$ is a very limiting nutrient in both acidic and alkaline soils, continued inputs of high-cost chemical $P$ fertilizers are required to increase and maintain plant production, although most ( $>90 \%$ ) of the applied $\mathrm{P}$ remains in the soil as inorganic and organic P (Nash et al., 2014; Mózner et al., 2012), and this continued input of fertilizer contributes to the deterioration of the environment especially through eutrophication (Song et al., 2017). In contrast, the addition of organic amendments activates Al-P and Fe-P in neutral and acidic soils and Ca-P in alkaline soil (Zhang et al., 2009), causing an increase in the levels of readily available P for use by plants. Ch'ng et al. (2014) concluded that amending acidic soil with biochar or compost or a mixture of biochar and compost increased total $\mathrm{P}$, available $\mathrm{P}$, inorganic $\mathrm{P}$ fractions and organic $\mathrm{P}$ in the soil. Al-Rohily et al. (2013) revealed that CM and sludge manure (SM) applications had appreciable and different impacts on the availability of $\mathrm{P}$ in calcareous soils than P from manure that was gradually transformed into available forms of $\mathrm{P}$ over time.
Different extraction methods were used in evaluating the status of available P in soil, which that was considered an important indicator for finding the capacity of the soil to supply P and for estimating the $\mathrm{P}$ fertilization rate and $\mathrm{P}$ loss risk from runoff (Shafqat and Pierzynski, 2013). Efficient extractants such as Bray and Kurtz-II and Mehlich-1 are designed to extract $P$ from non-calcareous soils, with Bray and Kurtz-I and Mehlich-3 from extracting P from acidic, slightly acidic and slightly alkaline soils, respectively. Kelowna extracts $\mathrm{P}$ from soils with a wider range of $\mathrm{pH}$ and Olsen from alkaline and neutral soils, but Olsen has also been shown in some research to be reasonably effective extracting $\mathrm{P}$ from acidic soils (Sims, 2000; Bray and Kurtz, 1945; Mehlich, 1984; Olsen et al., 1954).

Considerable effort has been put into understanding soil P chemistry especially as it relates to P fixation and availability from mineral fertilizer (Khasawneh et al., 1980). In comparison, less research has been devoted to understanding P availability from organic amendments. The ways these amendments affect soil extractable $\mathrm{P}$ is crucial to making nutrient management plans that maximize economic benefits and minimize environmental risks (Kashem et al., 2004). It is, however, important to compare the availability of $\mathrm{P}$ in different soils under different conditions for suitable P management. The objectives of this study, therefore, were to compare the extractable $\mathrm{P}$ in acidic and alkaline soils treated with CM, PM, CW and TSP fertilizer as $P$ sources to determine the changes in extractable $\mathrm{P}$ with time in soil treated with either organic or inorganic $\mathrm{P}$ sources and to compare the efficiency of extractable $\mathrm{P}$ extraction methods between acidic and alkaline soils. 


\section{Materials and Methods}

\subsection{Characteristics of the soils and organic amendments}

A sandy loam acidic soil (Aquepts) of the Pahartali series and a silt loam alkaline soil (Fluvents) of the Sara series of Bangladesh were used in this study. A composite soil sample was taken from the surface layer $(0-15 \mathrm{~cm})$ of the soil, air dried, and ground to pass through a 2-mm sieve. Organic amendments such as the cow manure (partially decomposed) used in this study were collected from the University of
Chittagong Campus near the botanical garden, and the poultry manure and city waste were collected from the Veterinary University of Chittagong and Halishahar of Chittagong, Bangladesh respectively. Soil properties and important characteristics of the amendments are presented in Table 1. Particle size analyses of the soil samples were done by a hydrometer method described by Day (1965). Textural classes of soil samples were determined by Marshall's triangular coordinates designed by the USDA (1951). The field capacity of the soil and moisture content of the soil samples and amendments were determined by the methods described by Black (1965).

Table 1. Characteristics of the soils and the amendments used.

\begin{tabular}{lllllll}
\hline Characteristics & Acidic soil & $\begin{array}{l}\text { Alkaline } \\
\text { soil }\end{array}$ & $\begin{array}{l}\text { Cow } \\
\text { manure }\end{array}$ & $\begin{array}{l}\text { Poultry } \\
\text { manure }\end{array}$ & City waste & TSP \\
\hline pH & $5.00 \pm 0.10^{\mathrm{z}}$ & $8.00 \pm 0.06$ & $7.00 \pm 0.15$ & $7.00 \pm 0.10$ & $8.00 \pm 0.21$ & \\
Moisture content (\%) & $2.00 \pm 0.06$ & $6.00 \pm 0.15$ & $2.00 \pm 0.06$ & $9.00 \pm 0.31$ & $5.00 \pm 0.25$ & \\
Field capacity (\%) & $28.00 \pm 0.30$ & $44.00 \pm 1.00$ & - & - & - & - \\
Sand (\%) & $68.00 \pm 0.71$ & $27.00 \pm 0.10$ & - & - & - & - \\
Silt (\%) & $13.00 \pm 0.23$ & $53.00 \pm 0.69$ & - & - & - & - \\
Clay (\%) & $19.00 \pm 0.06$ & $20.00 \pm 1.00$ & - & - & - & - \\
OC $\left(\mathrm{g} \mathrm{kg}^{-1}\right)$ & $3.40 \pm 0.10$ & $3.70 \pm 0.20$ & $97.90 \pm 0.35$ & $181.40 \pm 0.40$ & $50.10 \pm 0.10$ & \\
OM $\left(\mathrm{g} \mathrm{kg}^{-1}\right)$ & $5.90 \pm 0.00$ & $6.70 \pm 0.27$ & $168.70 \pm 0.25$ & $312.70 \pm 0.12$ & $86.40 \pm 0.06$ & \\
Total N $\left(\mathrm{g} \mathrm{kg}^{-1}\right)$ & $0.70 \pm 0.25$ & $1.60 \pm 0.20$ & $5.10 \pm 0.25$ & $11.20 \pm 0.25$ & $6.80 \pm 0.15$ & \\
Total P $\left(\mathrm{g} \mathrm{kg}^{-1}\right)$ & $0.29 \pm 0.02$ & $0.43 \pm 0.02$ & $4.50 \pm 0.50$ & $15.00 \pm 0.15$ & $4.80 \pm 0.21$ & $209.00 \pm 1.53$ \\
Available P $\left(\mathrm{g} \mathrm{kg}^{-1}\right)$ & $0.003 \pm 0.00$ & $0.009 \pm 0.00$ & $0.80 \pm 0.21$ & $2.63 \pm 0.15$ & $1.57 \pm 0.42$ & $209.00 \pm 0.26$ \\
$($ Olsen) & & & & & & \\
\hline
\end{tabular}

zeach number is a mean of 3 observations \pm SD

The $\mathrm{pH}$ of the soil samples and organic amendments were determined by using the Jenway glass electrode $\mathrm{pH}$ meter (UK) as described by Jackson (1958) with a soil to water ratio of 1:2.5 and an organic amendment to water ratio of $1: 5$, respectively. The organic carbon of both the soil and amendment samples was determined by the wet oxidation method (Walkley and Black, 1934). The organic matter was calculated by multiplying the percent value of the organic carbon by the Van Bemmelen factor, 1.724 (Piper, 1950). For the total $\mathrm{P}$, soils and amendments were digested by the $\mathrm{H}_{2} \mathrm{O}_{2}$ $\mathrm{H}_{2} \mathrm{SO}_{4}$ wet oxidation method as described by Akinremi et al. (2003) and were determined by using a UV-1800 UVVis spectrophotometer (Shimadzu, Japan) employing 
the vanadomolybdate yellow color method described by Jackson (1973). The total N was determined by the micro-Kjeldahl method described by Jackson (1973). The available $\mathrm{P}$ of the soil samples and amendments were extracted according to Olsen et al. (1954) and were determined by using a UV-1800 UV-Vis spectrophotometer (Shimadzu, Japan) following the ascorbic acid blue color method (Murphy and Riley, 1962).

\subsection{Incubation experiment}

The experiment was carried out using three organic amendments: CM, PM, and CW in comparison with TSP to measure the extractable $\mathrm{P}$ at different incubation times in two different soils (acidic soil and alkaline soil). One-hundred grams of air dry soil from each sample was mixed with the CM, PM, CW and $\mathrm{TSP}$ at rates equivalent to $200 \mathrm{mg} \mathrm{P} \mathrm{kg}{ }^{-1}$ in the soil based on the total $\mathrm{P}$ on an oven dry weight basis. The amount of total $\mathrm{N}$ among all the treatments was kept almost equal by applying urea at a rate of $200 \mathrm{mg}$ $\mathrm{N} \mathrm{kg}^{-1}$ in the TSP amended soil. Each treatment was replicated three times. The soil was incubated at field capacity for 15, 30 and 60 days at room temperature in plastic jars with perforated lids to allow gas exchange. The total number of jars was 90 [5 (amendments) $\times 2$ (soil) $\times 3$ (time) $\times 3$ (rep)]. The samples were weighed weekly, and additional water was added as required. Following incubation, the soil was air-dried, ground and passed through a 2-mm sieve for analysis. The soil $\mathrm{P}$ was extracted using four different extractants (Table 2). The $\mathrm{P}$ concentrations in the various extracts were determined by using a UV-1800 UV-Vis spectrophotometer (Shimadzu, Japan) following the ascorbic acid blue color method (Murphy and Riley, 1962). The extraction efficiency of the added $P$ was determined as [(net extractable P/added P) X 100] after each incubation time where net extractable $\mathrm{P}$ is the difference between the $\mathrm{P}$ in the amended and the control soils at each incubation time.

Table 2. Different methods used for extracting P from soils.

\begin{tabular}{|c|c|c|c|c|}
\hline Methods & Extracting Solution & $\begin{array}{l}\text { Soil to solution } \\
\text { ratio }(\mathrm{W}: \mathrm{V})\end{array}$ & Extraction time & Reference \\
\hline Olsen & $0.5 \mathrm{M} \mathrm{NaHCO}_{3}, \mathrm{pH} 8.5$ & $1: 20$ & $\begin{array}{l}30 \text { min at } 120 \\
\text { strokes per min }\end{array}$ & Olsen et al. (1954) \\
\hline Mehlich-3 & $\begin{array}{l}0.2 \mathrm{~N} \mathrm{CH}_{3} \mathrm{COOH}+ \\
0.013 \mathrm{~N} \mathrm{HNO}_{3}+0.015 \mathrm{~N} \\
\mathrm{NH}_{4} \mathrm{~F}+0.25 \mathrm{~N} \mathrm{NH}_{4} \\
\mathrm{NO}_{3}+0.001 \mathrm{M} \text { EDTA }\end{array}$ & $1: 10$ & $\begin{array}{l}5 \text { min at } 120 \\
\text { strokes per min }\end{array}$ & Mehlich (1984) \\
\hline Kelowna & $\begin{array}{l}0.25 \mathrm{M} \mathrm{CH}_{3} \mathrm{COOH}+ \\
0.015 \mathrm{M} \mathrm{NH}_{4} \mathrm{~F}\end{array}$ & $1: 10$ & $\begin{array}{l}15 \text { min at } 180 \\
\text { strokes per min }\end{array}$ & Van Lierop (1988) \\
\hline Bray and Kurtz -II & $0.03 \mathrm{~N} \mathrm{NH}_{4} \mathrm{~F}+0.1 \mathrm{~N} \mathrm{HCI}$ & $1: 10$ & $\begin{array}{l}1 \text { min at } 200 \\
\text { strokes per min }\end{array}$ & Bray and Kurtz (1945) \\
\hline
\end{tabular}




\subsection{Statistical analyses}

The results were statistically evaluated by Pearson correlation coefficient, analysis of variance (ANOVA), regression equation and descriptive statistics by using the Minitab program (Release 11, Minitab Inc., 1996).

\section{Results}

\subsection{Effects of amendment on extractable $P$}

Regardless of the extraction method, there were significant differences in the extractable $\mathrm{P}$ among the amendments; however, these differences were in the types of soils and time dependent (Table 4).
The results obtained after 15 days of incubation, as extracted by $\mathrm{NaHCO}_{3}(\mathrm{Olsen}-\mathrm{P})$, in both acidic and alkaline soils are used to illustrate the amendment effect on the extractable P. The trends in the data obtained with other extractants were similar to that of Olsen-P (Table 3). After 15 days, the highest soluble P source from the acidic soil was TSP, with an Olsen-P of 88 mg kg-1, which represents $39 \%$ of the added TSP. The city waste, on the other hand, had the lowest extractable $\mathrm{P}$, accounting for $11 \mathrm{mg} \mathrm{kg}^{-1}$, which represents approximately $15 \%$ of added $\mathrm{CW}$. The extractable $\mathrm{P}$ in the soil amended with $\mathrm{CM}\left(41 \mathrm{mg} \mathrm{kg}^{-1}\right)$ and PM (71 $\mathrm{mg} \mathrm{kg}^{-1}$ ) was intermediate between TSP and CW. The results obtained for the alkaline soil after 15 days were similar to that of the acidic soil (Table 3).

Table 3. Extractable P concentration $\left(\mathrm{mg} \mathrm{kg}^{-1}\right)$ following incubation of amended acidic and alkaline soils.

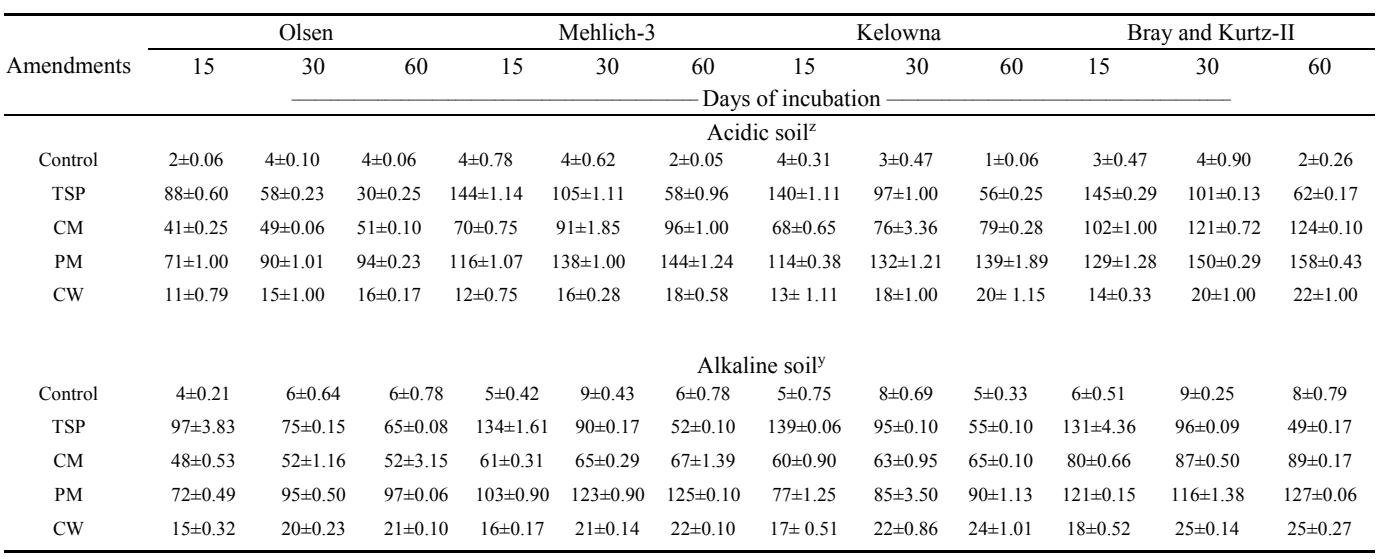

${ }^{\mathrm{z}}$ each number is a mean of 3 observations $\pm \mathrm{SD}$; ${ }^{\mathrm{y}}$ each number is

a mean of 3 observations $\pm \mathrm{SD}$

Olsen $=\mathrm{NaHCO}_{3}$-extractable $\mathrm{P} ;$ Mehlich $3=$ Mehlich 3-extract-

able P; Kelowna = Kelowna-extractable $\mathrm{P}$ and Bray and Kurtz

$\mathrm{II}=$ Bray and Kurtz-II-extractable P

$\mathrm{TSP}=$ Triple Super Phosphate; $\mathrm{CM}=$ Cow Manure; $\mathrm{PM}=$ Poultry

Manure; $\mathrm{CW}=$ City Waste 
Table 4. F-values of the analysis of variance of the effect of amendments, rate and time on the extractable P.

\begin{tabular}{lcccc}
\hline Treatment & Olsen & Mehlich-3 & Kelowna & Bray and Kurtz-II \\
\hline & \multicolumn{5}{c}{ Acidic soil } \\
Amendment & $65^{* *}$ & $85^{* *}$ & $86^{* *}$ & $110^{* *}$ \\
Time & $14^{* *}$ & $18^{* *}$ & $7^{*}$ & $15^{* *}$ \\
Amendment x Time & $26^{* *}$ & $19^{*}$ & $22^{* *}$ & $35^{* *}$ \\
& \multicolumn{5}{c}{ Alkaline soil } \\
Amendment & $173^{* *}$ & $71^{* *}$ & $51^{* *}$ & $80^{* *}$ \\
Time & 28 & 31 & $\mathrm{NS}$ & $\mathrm{NS}$ \\
Amendment x Time & 19 & 23 & $4^{*}$ & $3^{*}$ \\
\hline *** Significant at $p<0.05$ and $p<0.01$, respectively; NS, not significant
\end{tabular}

\subsection{Effects of incubation time on extractable $P$}

The effect of incubation time on the extractable $\mathrm{P}$ in the amended soil depends on the type of amendment and soil (Table 4). The Olsen-P data obtained in acidic and alkaline soils are used to illustrate the effect of incubation time (Table 3). In the acidic soil, the TSP-P declined sharply with an incubation time up to 60 days. For example, the Olsen P from the TSP-amended acidic soil declined from $88 \mathrm{mg} \mathrm{kg}^{-1}$ after 15 days to $30 \mathrm{mg} \mathrm{kg}^{-1}$ after 60 days, a $66 \%$ reduction. The corresponding decrease in Olsen $\mathrm{P}$ in alkaline soil was more gradual, and most of the $P$ changes occurred during the first 30 days.

The extractable $\mathrm{P}$ in the organic-amended soils, on the other hand, increased slightly with incubation time. In the acidic soil, Olsen P from CW-amended soil increased from $11 \mathrm{mg} \mathrm{kg}^{-1}$ after 15 days to 16 $\mathrm{mg} \mathrm{kg}^{-1}$ after 60 days, a $46 \%$ increase (Table 3). The corresponding value of Olsen $\mathrm{P}$ in the $\mathrm{CW}$-amended alkaline soil was $15 \mathrm{mg} \mathrm{kg}^{-1}$ after 15 days increasing to $21 \mathrm{mg} \mathrm{kg}^{-1}$ after 60 days of incubation, indicating a net mineralization of CW-P.

\subsection{Efficiency of added $P$}

The efficiency of added P varied with the amendment, soil, time of incubation and the extractants used (Table 5). In both soils, the extraction efficiency was in the order of Bray and Kurtz-II> Mehlich-3> Kelowna> Olsen. The results obtained with the Olsen extractants were used to illustrate the percent efficiency of the added $\mathrm{P}$. The $\mathrm{P}$ efficiency with the $\mathrm{CW}$ increased from $4 \%$ after 15 days to $6 \%$ after 60 days of incubation in the acidic soil. The corresponding values in the alkaline soil were 6 and $7 \%$ after 15 and 60 days of incubation, respectively. With the $\mathrm{CM}$, the efficiency was lower in the acidic soil (19\%) than that in the alkaline soil (22\%) after 15 days of incubation. In contrast to the $\mathrm{CM}$, the PM provided a higher efficiency $(35 \%)$ in the acidic soil than that in the alkaline soil (34\%) after 15 days of incubation. These efficiencies slightly increased after 30 days of incubation while remaining relatively constant after 60 days of incubation with both the CM and PM. Among the amendments, efficiency was consistently greatest with the TSP in the acidic soil (43\%) and the alkaline soil (46\%) after 15 days of incubation. However, the TSP produced the smallest efficiency of $13 \%$ in the acidic soil and $30 \%$ in the alkaline soil after 60 days of incubation (Table 5). 
Table 5. Efficiency of extractable P (\%) for both soils and P sources at 15, 30 and 60 days of incubation.

\begin{tabular}{|c|c|c|c|c|c|c|c|c|c|c|c|c|}
\hline \multirow{2}{*}{ Amendments } & Olsen & Mehlich-3 & Kelowna & Bray \& Kurtz-II & Olsen & Mehlich-3 & Kelowna & Bray \& Kurtz-II & Olsen & Mehlich-3 & Kelowna & Bray \& Kurtz-II \\
\hline & \multicolumn{8}{|c|}{15 days } & \multicolumn{4}{|c|}{60 days } \\
\hline & \multicolumn{12}{|c|}{ Acidic soil $^{2}$} \\
\hline TSP & $43 \pm 0.28$ & $70 \pm 0.15$ & $68 \pm 0.12$ & $71 \pm 0.13$ & $27 \pm 0.45$ & $51 \pm 0.06$ & $47 \pm 0.00$ & $49 \pm 0.24$ & $13 \pm 0.31$ & $28 \pm 0.18$ & $28 \pm 0.20$ & $30 \pm 0.08$ \\
\hline $\mathrm{CM}$ & $19 \pm 0.43$ & $33 \pm 0.21$ & $32 \pm 0.23$ & $49 \pm 0.25$ & $23 \pm 0.32$ & $44 \pm 0.42$ & $37 \pm 0.40$ & $58 \pm 0.45$ & $24 \pm 0.32$ & $47 \pm 0.40$ & $39 \pm 0.10$ & $61 \pm 0.18$ \\
\hline $\mathrm{PM}$ & $35 \pm 0.58$ & $56 \pm 0.20$ & $56 \pm 0.40$ & $63 \pm 0.05$ & $43 \pm 0.10$ & $67 \pm 0.34$ & $65 \pm 0.46$ & $73 \pm 0.12$ & $46 \pm 0.36$ & $71 \pm 0.09$ & $69 \pm 0.25$ & $78 \pm 0.23$ \\
\hline \multirow[t]{2}{*}{$\mathrm{CW}$} & $4 \pm 0.10$ & $4 \pm 0.06$ & $5 \pm 0.15$ & $6 \pm 0.06$ & $6 \pm 0.06$ & $6 \pm 0.10$ & $8 \pm 0.15$ & $8 \pm 0.15$ & $6 \pm 0.25$ & $8 \pm 0.55$ & $9 \pm 0.67$ & $10 \pm 0.12$ \\
\hline & \multicolumn{12}{|c|}{ Alkaline soil $y$} \\
\hline TSP & $46 \pm 0.15$ & $65 \pm 0.31$ & $67 \pm 0.60$ & $62 \pm 0.14$ & $35 \pm 0.06$ & $41 \pm 0.10$ & $43 \pm 0.21$ & $44 \pm 0.25$ & $30 \pm 0.10$ & $23 \pm 0.50$ & $25 \pm 0.38$ & $21 \pm 1.00$ \\
\hline $\mathrm{CM}$ & $22 \pm 0.75$ & $28 \pm 0.46$ & $28 \pm 0.76$ & $37 \pm 0.28$ & $23 \pm 0.33$ & $28 \pm 0.25$ & $27 \pm 0.10$ & $39 \pm 0.00$ & $23 \pm 0.40$ & $31 \pm 0.06$ & $30 \pm 0.90$ & $41 \pm 0.00$ \\
\hline $\mathrm{PM}$ & $34 \pm 0.47$ & $49 \pm 0.08$ & $36 \pm 0.57$ & $58 \pm 0.51$ & $44 \pm 0.34$ & $57 \pm 0.22$ & $38 \pm 0.29$ & $53 \pm 0.31$ & $45 \pm 1.00$ & $60 \pm 0.61$ & $42 \pm 0.12$ & $60 \pm 0.06$ \\
\hline $\mathrm{CW}$ & $6 \pm 1.10$ & $6 \pm 0.27$ & $6 \pm 0.25$ & $6 \pm 0.27$ & $7 \pm 0.13$ & $6 \pm 0.06$ & $7 \pm 0.10$ & $8 \pm 1.6$ & $7 \pm 0.06$ & $8 \pm 0.20$ & $9 \pm 0.64$ & $9 \pm 0.00$ \\
\hline
\end{tabular}

${ }^{z}$ each number is a mean of 3 observations $\pm \mathrm{SD}$; ${ }^{\mathrm{y}}$ each number is a mean of 3 observations $\pm \mathrm{SD}$

TSP: Triple Super Phosphate; CM: Cow Manure; PM: Poultry Manure; CW: City Waste

3.4. Comparison of $P$ extractability among extractants

A wide variation was observed in the extractable $\mathrm{P}$ values obtained in the acidic and the alkaline soils by all the methods used in this study (Table 3). Considering the mean extractable P by the various methods, Olsen extracted the least amount of P while Bray and
Kurtz-II extracted the highest amount of $\mathrm{P}$ in both soils. The amount of $\mathrm{P}$ extracted from the amended acidic and alkaline soils increased in the order of Bray and Kurtz-II $>$ Mehlich-3> Kelowna $>$ Olsen (Figure 1 ). The amount of $P$ extracted by the various extractants increased with the increasing acidity of the extracting solution. However, the Olsen extractant was more suitable for alkaline soil than for acidic soil.

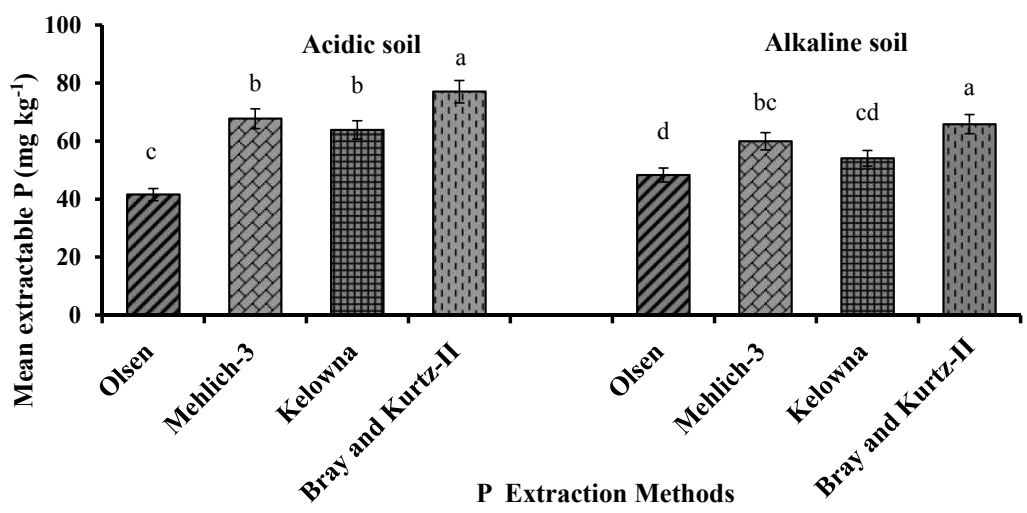

Figure 1. Mean of $\mathrm{P}$ extracted by different soil $\mathrm{P}$ extraction methods. Means indicated with the different letters were significantly different at $P<0.05(\mathrm{n}=45)$. 
Tukey's test for the multiple means comparison showed that the means of Olsen and Bray and KurtzII, Olsen and Mehlich-3, Olsen and Kelowna, Kelowna and Bray and Kurtz-II in acidic soil and Olsen and Bray and Kurtz-II, Kelowna and Bray and Kurtz-II and Mehlich-3 and Bray and Kurtz-II in alkaline soil are significantly different $(p<0.05)$, while no significant differences were observed in the means of Mehlich-3 and Bray and Kurtz-II in acidic soil and Olsen and Mehlich-3 and Olsen and Kelowna in alkaline soil (Figure 1).

To ascertain whether the extractants used in this study could provide a comparable and consistent evaluation of the extractable P pool, values of soil extractable $\mathrm{P}$ as measured by the different extractants were related to each other using a correlation analysis. The $\mathrm{P}$ extraction methods were significantly correlated in acidic ( $r=0.97$ to 0.99$)$ and alkaline soils $(r=0.94$ to 0.98 ) indicating that any of these extractants can be used to estimate extractable $P$ in acidic and alkaline soils. The regression equations showed that there were highly significant linear relationships $(p<0.01)$ among the different soil $\mathrm{P}$ test methods with coefficient of determination, $\mathrm{R}^{2}$, values ranging between 0.942 and 0.998 in the acidic soil and between 0.942 and 0.998 in the alkaline soil (Figure 2).
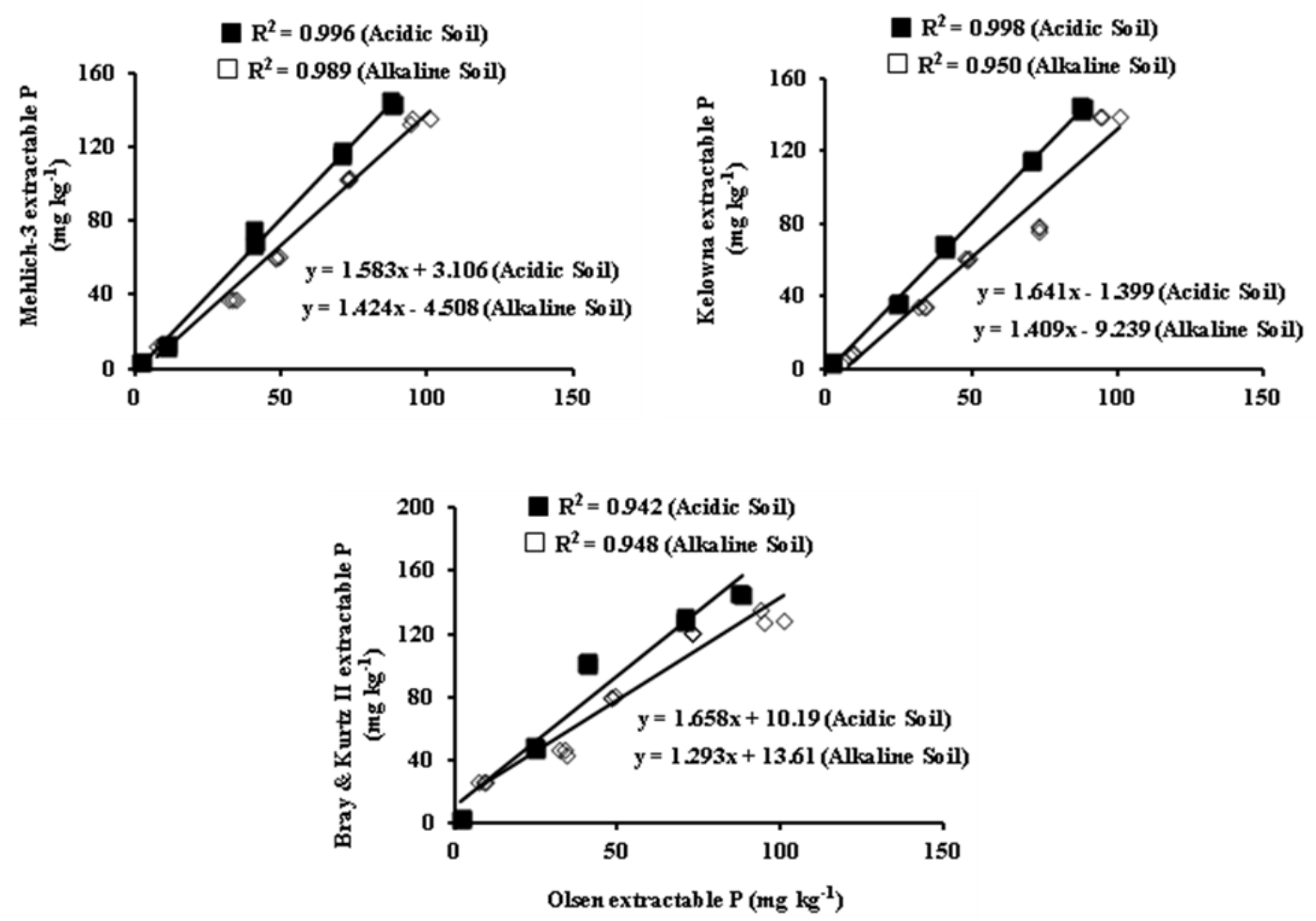

Figure 2. Relationships between Olsen extractable P vs. Mehlich-3, Kelowna and Bray and Kurtz-II extractable $\mathrm{P}$ after 15 days of incubation. 


\section{Discussion}

This study showed that the extractable $\mathrm{P}$ in both acidic and alkaline soils increased with the addition of amendments from different P sources. Regardless of the extractants and soils, the highest extractable $\mathrm{P}$ source was the TSP, and the lowest was the CW in soils. The extractable $\mathrm{P}$ with the $\mathrm{CM}$ and $\mathrm{PM}$ was at values between those for TSP and CW. Similar findings were observed in other studies (Kashem et al., 2004; Ige et al., 2006; McCoy et al., 1986). Kashem et al. (2004) conducted an incubation study with biosolids (treated city waste), hog and cattle manures and monoammonium phosphate (MAP) and demonstrated that biosolids had the lowest extractable P, while MAP had the highest extractable P after 1 week of incubation. However, extractable $\mathrm{P}$ in hog manure and cattle manure was at an intermediate level between biosolids and MAP. The relatively small extractable $\mathrm{P}$ with the biosolids may be due to anaerobic digestion and the addition of polymers to flocculate the biosolids. These polymers contain cations that are capable of fixing P (Hamad et al., 1992). McCoy et al. (1986) reported that biosolid $\mathrm{P}$ was four to seven times less available to plants than P in the TSP. Saleem et al. (2017), on the other hand, reported that $P$ in poultry manure was very effective as $\mathrm{P}$ in the fertilizer because it contains 88 to $90 \%$ inorganic P. Our results indicate that there would be less environmental problems associated with CW-P compared with that of other amendments at equal loadings of total $\mathrm{P}$, due to the smaller lability of CW-P in the soil.

The changes of extractable $\mathrm{P}$ with incubation time in different amendments were remarkable and differed with extraction methods and soil types. Among the amendments, extractable $\mathrm{P}$ in the soils with the organic amendments increased slightly with increasing incubation time. However, with the TSP, extractable P decreased sharply in the acidic soil, while it decreased gradually in the alkaline soil. Triple super phosphate contains P mostly in the inorganic soluble form, a portion of which, on incubation, was in solubilized in the soil. In contrast, P in the organic amendments was mostly present in the organic form that could be mineralized to release available $\mathrm{P}$ in the soil. Such mechanisms could be responsible for the increase in $P$ from the TSP and the decrease in P from the organic amendments with incubation time. Other studies also note similar findings (Kashem et al., 2004; Zhang et al., 2009; Ch'ng et al., 2014; Al-Rohily et al., 2013; Vásconez and Pinochet, 2018).

The differences in the magnitude of the changes in extractable P between the TSP and organic amendments indicate different $\mathrm{P}$ retention mechanisms in the soils (Ajiboye et al., 2003; Kashem et al., 2004). The fertilizer $\mathrm{P}$ was mixed with the soil in the form of granules. High $\mathrm{P}$ concentrations around the granules would likely favor the precipitation of $\mathrm{P}$ as dicalcium phosphate dehydrates (Kashem et al., 2004). In contrast, with the organic amendments, the low concentration of $\mathrm{P}$ will favor sorption and desorption rather than precipitation (Kashem et al., 2004; Ajiboye et al., 2003). Ajiboye et al. (2003) reported that the $\mathrm{P}$ saturation index (PSI), a measure of the degree of $\mathrm{P}$ saturation, was smaller with MAP compared to that with hog and cattle manures in the Osborne soil (slightly alkaline soil). The relatively small value of PSI with MAP in the Osborne soil may be because the mechanism of $\mathrm{P}$ retention in the MAP-amended Osborne soil was precipitation.

A wide variation was observed in the extractability of $\mathrm{P}$ among the extractants in the acidic and the alkaline soils. Among the extractants, Bray and Kurtz-II extracted the highest amount of $\mathrm{P}$ while Olsen extracted the least amount of P in both soils. Sims (2000) noted that the Olsen extractant has less ability to remove $\mathrm{P}$ from the soil than the acidic extractants. Bray and Kurtz-II, the most acidic, extracted the greatest 
amount of $\mathrm{P}$ while Olsen, the most alkaline, extracted the least amount of $\mathrm{P}$ of all the soil test methods. This result is probably because as the $\mathrm{pH}$ of the extracting solution decreases, more of the phosphate associated with Ca dissolves (Ige et al., 2006). Moreover, the differences among the $\mathrm{P}$ extraction methods probably arose because plant available $\mathrm{P}$ in the soil is not from a discrete fraction but from a continuum of fractions; extracting agents preferentially extract from different fractions depending on their reaction with the soil components involved in P sorption (Council for Agricultural Science and Technology, 2000). In addition, each extracting solution has a different ability to extract varying portions of soil $\mathrm{P}$ because they were targeted at different pools of soil P (Zhang et al., 2004). A correlation analysis was performed among different $\mathrm{P}$ extraction methods and it showed that the P extraction methods were highly correlated in both acidic and alkaline soils. Similar results were also observed in other studies (Zhang et al., 2004; Kashem et al., 2004; Ige et al., 2006). The regression equations also showed that there were highly significant linear relationships $(p<0.01)$ among the different soil $\mathrm{P}$ test methods in the acidic and the alkaline soils. Ige et al. (2006) reported a coefficient of determination, $\mathrm{R}^{2}$, values ranging between 0.91 and 0.97 among water extraction, Olsen, Kelowna-1, Kelowna-2, Kelowna-3 and Mehlich-3 methods. Zhang et al. (2004), working with a set of Alberta soils in Canada, also reported a high regression coefficient between the various $\mathrm{P}$ extraction methods. The significant linear relationship among the soil test methods indicates that the results from one soil test $\mathrm{P}$ method can be converted to another using the equations generated in this study (Zhang et al., 2004; Kashem et al., 2004; Ige et al., 2006). The efficiency of added $\mathrm{P}$ from different organic and inorganic sources is very important to a sound management of $\mathrm{P}$ addition to agricultural soils. This study showed that the PM provided a higher efficiency in both acidic and alkaline soils after 15 days of incubation followed by $\mathrm{CM}$ while the $\mathrm{CW}$ provided a lower efficiency among the organic amendments. These efficiencies slightly increased after 30 days of incubation while remaining relatively constant after 60 days of incubation. Triple super phosphate, on the other hand, provided the highest efficiency among amendments after 15 days of incubation and its efficiency decreased with days of incubation. These findings have practical implications for soil testing following the application of these amendments in the field. Farmers may be interested in knowing how soon after applying manure they should test their soil to provide a good reflection of plant available P. Our results suggest that extractable $\mathrm{P}$ at 30 days of incubation of soils amended with $\mathrm{CM}$ and PM was generally the highest. Therefore, soil samples taken 30 days following the addition of CM and PM might reflect sufficient plantavailable $P$.

\section{Conclusions}

Extractable $\mathrm{P}$ increased in the soils amended with organic $\mathrm{P}$ sources, but the increase varied with the $\mathrm{P}$ sources of the different amendments. The city waste produced the smallest extractable P, while the TPS produced the highest extractable $\mathrm{P}$ in both acidic and alkaline soils. The level of extractable $\mathrm{P}$ with the $\mathrm{CM}$ and PM was at values between those for TSP and CW. Among the amendments, soil extractable P under the organic amendment increased slightly with increasing incubation time. In contrast, extractable $\mathrm{P}$ in the TSPamended soils decreased with incubation time; however, the decrease was twofold higher in the acidic soil than that in the alkaline soil. The high correlation coefficient among the various extractants shows that all of them will provide a good index of P lability in these soils. Among the extractants, Bray and KurtzII shows a higher extractability while Olsen shows a 
lower extractability in both soils. Our results suggest that soil samples taken 30 days following the addition of CM and PM should reflect plant-available P. For the CW, soil samples taken within the same period following application are likely to underestimate plant-available $\mathrm{P}$. The results also indicate that the $\mathrm{P}$ in the organic amendments behaved differently upon addition to different soils, and these differences should be taken into consideration in managing their land application. Moreover, future works are needed to justify these effects with plant uptake.

\section{Acknowledgements}

The authors thank the Authority of the University of Chittagong, Bangladesh for sanctioning the financial assistance to conduct this research.

\section{References}

Adnan, A., Mavinic, D.S., Koch, F.A. 2003. Pilotscale study of phosphorus recovery through struvite crystallization-examining to process feasibility. J. Environ. Eng. Sci. 2(5), 315-324.

Ajiboye, B., Akinremi, O.O., Racz, G.J. 2003. Retention characteristics of phosphorus in manured and fertilized soils. In Proceedings of 46th Annual Manitoba Society of Soil Science Meeting, Winnipeg, MB. 20-21 January.

Akinremi, O.O., Armisen, N., Kashem, A., Janzen, H.H. 2003. Evaluation of analytical methods for total phosphorus in organic amendments. Commun. Soil Sci. Plant Ana. 34, 2981-2991.

Al-Rohily, K.M., Ghoneim, A.M., Modaihsh, A.S., Mahjoub, M.O. 2013. Phosphorus availability in calcareous soil amend with chemical phosphorus fertilizer, cattle manure compost and sludge manure. Int. J. Soil Sci. 8, 17-24.
Arai, Y., Sparks, D.L. 2007. Phosphate reaction dynamics in soils and soil components: A multiscale approach. Adv. Agron. 94, 135-179.

Black, C.A. 1965. Methods of Soil Analysis. Part H. Agron. Series 9. Ann. Soc. Agron. Ins. Publisher Madison, Wise.

Bray, R.H., Kurtz, L.T. 1945. Determination of total, organic and available form of phosphorus in soil. Soil Sci. 59, 39-45.

Ch'ng, H.Y., Ahmed, O.H., Majid, N.M.A. 2014. Improving phosphorus availability in an acid soil using organic amendments produced from agroindustrial wastes. Sci. World J. 2014, 1-6.

Council for Agricultural Science and Technology, 2000. Relevance of Soil Testing to Agriculture and the Environment, CAST, Ames, pp: 1-12.

Day, P.R. 1965. Particle fractionation and particle size analysis. In: Black C. A. (ed.). Methods of Soil Analysis, Part 1. Agronomy Monograph 9. ASA, Madison, WI, pp: 545-567.

Devau, N., Le Cadre, E., Hinsinger, P., Gérard, F. 2010. A mechanistic model for understanding root-induced chemical changes controlling $\mathrm{P}$ availability. Ann. Bot. (Lond.) 105, 1183-1197.

Hamad, M.E., Rimmer, D.L., Syers, J.K. 1992. Effect of iron oxide on phosphate retention by calcite and calcareous soils. J. Soil Sci. 43, 273-281.

Ige, D.V., Akinremi, O.O., Flaten, D., Kashem, M.A. 2006. Comparison of soil test phosphorus methods in neutral to calcareous Manitoba soils. Can. J. Soil Sci. 86, 691-699.

Jackson, M.L. 1973. Soil Chemical Analysis. Printice Hall of India (Pvt.) Limited, New Delhi, India.

Jackson, M.I. 1958. Soil Chemical Analysis. Constable and Co. Ltd., London.

Kashem, M.A., Akinremi, O.O., Racz, G.J. 2004. Extractable phosphorus in alkaline soils amended 
with high rates of organic and inorganic phosphorus. Can. J. Soil Sci. 84, 459-467.

Khasawneh, E.F., Sample, E.C., Kamprath, E.J. 1980. The role of phosphorus in agriculture. ASA/ CSSA/SSSA, Madison.

McCoy, J.L., Sikora, L.J., Weil, R.R. 1986. Plant availability of phosphorus in sewage sludge compost. J. Environ. Qual. 15, 403-409.

Mehlich, A. 1984. Mehlich 3 Soil Extractant. A modification of Mehlich 2 extractant. Commun. Soil Sci. Plant Anal. 15, 1409- 1416.

Mózner, Z., Tabi, A., Csutora, M. 2012. Modifying the yield factor based on more efficient use of fertilizer-the environmental impacts of intensive agricultural practices. Ecol. Indic. 16, 58-66.

Murphy, J., Riley, J.P. 1962. A modified single solution methods for the determination of available phosphate in natural water. Acta Analytica. 27, 31-36.

Naeem, A., Akhtar, M., Ahmad, W. 2013. Optimizing available phosphorus in calcareous soils fertilized with diammonium phosphate and phosphoric acid using Freundlich adsorption isotherm. Sci. World J. 2013, 1-5.

Nash, D., Haygarth, P., Turner, B., Condron, L., McDowell, R., Richardson, A., Watkins, M., Heaven, M. 2014. Using organic phosphorus to sustain pasture productivity: A perspective. Geoderma. 221-222, 11-19.

Olsen, S.R., Cole, C.V., Watanabe, F.S., Dean, L.A. 1954. Estimation of available phosphorus in soils by extraction with sodium bicarbonate. USDA circular no.939. U.S. Govt. Print Washington, D.C.
Piper, C.S. 1950. Soil and Plant Analysis. Hassel press. Adelaide, Australia.

Saleem, A., Irshad, M., Hassan, A., Mahmood, Q., Eneji, A. E. 2017. Extractability and bioavailability of phosphorus in soils amended with poultry manure co-composted with crop wastes. J. Soil Sci. Plant Nutr. 17, 609-623

Shafqat, M.N., Pierzynski, G.M. 2013. Soil test P dynamics in animal waste amended soils: Using $\mathrm{P}$ mass balance approach. Chemosphere. 90, 691-698.

Sims, J.T. 2000. Soil test P: Olsen P. In: Pierzynski, G. M. (ed.) Methods of P analysis for soils, sediments, residuals, and waters. Manhattan: Kansas State University. pp: 20-21.

Song, K., Xue, Y., Zheng, X., Lv, W., Qiao, H., Qin, Q., Yang, J. 2017. Effects of the continuous use of organic manure and chemical fertilizer on soil inorganic phosphorus fractions in calcareous soil. Sci. Rep. 7, 1164.

Ulrich, A., Schnug, E. 2013. The modern P sustainability movement: A profiling experiment. Sustainability. 5, 4523-4545.

USDA, 1951. Soil Survey Manual. Soil Survey Staff. Bureau of Plant Industry, Soil and Agricultural Engineering. Handbook no. 18:205. US Govt. Printing Officer. Washington, D.C.

Vásconez, G., Pinochet, D. 2018. Residual value of the phosphate added to ecuadorian and chilean soils with different phosphorus retention capacity. J. Soil Sci. Plant Nutr. 18, 60-72.

Walkley, A., Black, I.A. 1934. An examination of Kjeldahl method for determining soil organic matter and a proposed modification of the chromic acid titration method. Soil Sci. 37, 29-38. 
Zhang, A., He, L., Zhao, H., Wu, Z., Guo, Z., Li, S. 2009. Effect of organic acids on inorganic $P$ transformation in soil with different P sources. Chin. J. Appl. Environ. Biol. 15, 474- 478.
Zhang, M., Wright, R., Heaney, D., Vanderwel, D. 2004. Comparison of different phosphorus extraction and determination methods using manured soils. Can. J. Soil Sci. 84, 469-475. 